\title{
Eccrine Hidrocystoma in External Auditory Canal
}

\author{
Young Sub Lee, Chun Han, Cheol Hyo Ku, and Young Joon Seo \\ Department of Otorhinolaryngology, Yonsei University Wonju College of Medicine, Wonju, Korea
}

\section{외이도의 에크린 한선종}

\author{
이영섭 · 한 준·구철효 · 서영준 \\ 연세대학교 원주의과대학 이비인후과학교실
}

\author{
Received June 24, 2016 \\ Revised August 28, 2016 \\ Accepted September 5, 2016 \\ Address for correspondence \\ Young Joon Seo, MD \\ Department of Otorhinolaryngology, \\ Yonsei University \\ Wonju College of Medicine, \\ 20 Ilsan-ro, Wonju 26426, Korea \\ Tel $+82-33-741-0642$ \\ Fax $+82-33-732-8287$ \\ E-mail okas2000@yonsei.ac.kr
}

Hidrocystomas, eccrine or apocrine are rare ductal cystic benign lesions of the sweat gland. These uncommon cystic lesions are extremely rare in the external ear. Here, we discuss the clinical features and management of eccrine hydrocystoma in the external ear by describing the clinical, radiographic, pathologic features and management of an external auditory canal eccrine hidrocystoma in a 73-year-old Korean man. To the best of our knowledge, this tumor has not been reported previously in this site. Five month after surgery, there has been no evidence of local recurrence. Korean J Otorhinolaryngol-Head Neck Surg 2017;60(12):670-2

\section{서 론}

한선 낭종(hidrocystoma)은 땀샘에서 발생되는 드문 유관 낭성 양성 병변이다. 조직학적으로, 아포크린 한선 낭종(apocrine hidrocystoma)과 에크린 한선 낭종(eccrine hidrocystoma)으로 나뉘어진다. 아포크린 한선 낭종은 아포크린 샘 에서 발생하며 3 15 mm 직경의 단일 병변을 주로 이룬다. ${ }^{1)}$ 주로 두경부와 눈꺼풀의 주위를 따라서 눈의 양단 근처에 호 발하며 진한 푸른색을 띠는 경우가 많다. ${ }^{2}$ 반면에 에크린 한 선 낭종은 작고, 단단하고, $1 \sim 6 \mathrm{~mm}$ 직경의 얇은 벽의 낭종이 며 단일 혹은 다양한 병변으로 나타난다. 주로 30대에서 70 대 사이의 성인 여성에서 호발하며, 주된 병변 부위는 눈 주 위나 광대뼈 근처이다. ${ }^{3)}$ 이러한 한선 낭종은 2016년 7월 현재, 전 세계적으로 외이도에 발생한 경우는 총 4예가 보고되었으 며, 우리나라에서는 아직 보고된 바 없는 상황이다." ${ }^{4}$ 본 저자 들은 외이도에 발생한 에크린 한선 낭종을 경험하였기에 이

This is an Open Access article distributed under the terms of the Creative Commons Attribution Non-Commercial License (http://creativecommons.org/licenses/by-nc/4.0) which permits unrestricted non-commercial use, distribution, and reproduction in any medium, provided the original work is properly cited.
를 보고하고자 한다.

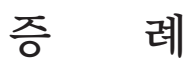

73세 남자 환자가 내원 3주 전부터 발생한 우측 외이도 출 혈, 통증을 주소로 이비인후과에 내원하였다. 과거력상 고혈 압, 만성 신부전을 않고 있었으며, 우측 $70 \mathrm{~dB}$, 좌측 $60 \mathrm{~dB}$ 의 양측 감각신경성 난청으로 좌측에 보청기를 10 년간 착용 하고 있었다. 중이염이나 귀 수술의 과거력은 없었다. 이내시 경 진찰 시 우측 외이도 후방에서 약 $2 \times 2 \mathrm{~mm}$ 크기의 갈색 을 띠는, 무경성 폴립 모양의 종양이 발견되었다. 촉진 시 환 자는 압통을 호소하였으며 종양에서 출혈 소견이 있었다 (Fig. 1). 폴립에 궤양 소견이 있었으며 1차 의료기관에서 2주 간의 항생제 치료에도 불구하고 호전이 없었기 때문에 외이 도 암 의증하에 세균검사보다는 병변의 중앙부에 국소마취 후 펀치 생검을 1회 시행하였다. 환자는 진통제와 함께 3세대 세팔로스포린 항생제, 점이액을 일주일간 사용하며 매일 상 처치료를 받았다.

일주일 후 환자는 이 통증이 많이 가라앉은 상태로, 지난번 
펀치 생검 결과는 반응성 섬유화를 동반한 급성 화농성 염 증 소견으로 보고되었다. 펀치 생검 이후 시행한 측두골 전산 화단층촬영에서 중이강 내 병변은 보이지 않았으나 외이도 후 벽에 $2.8 \times 6.92 \mathrm{~mm}$ 크기의 무경성 폴립 모양의 병변이 보이

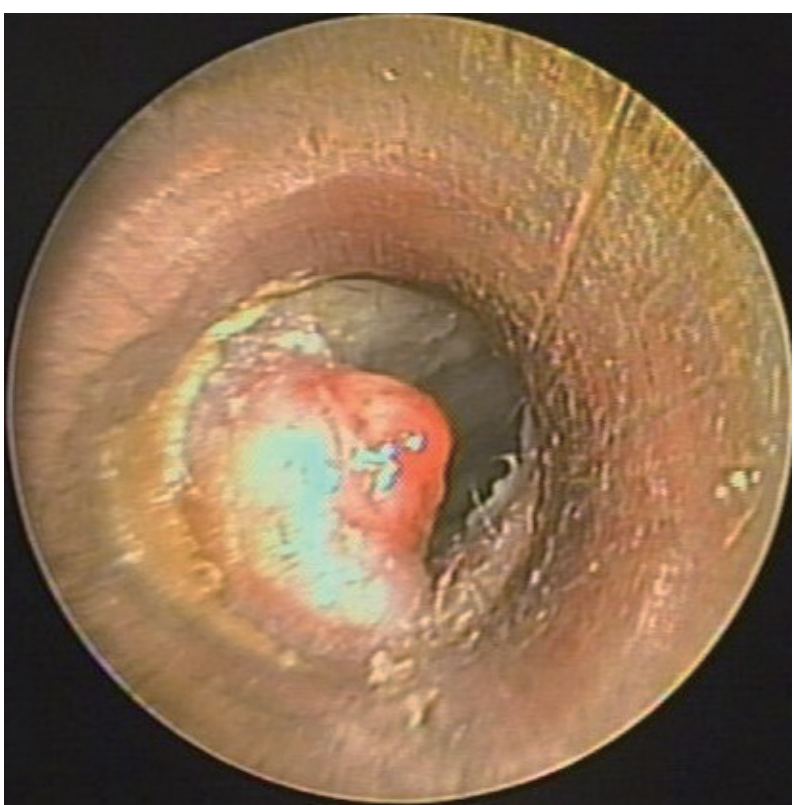

Fig. 1. The physical examination showed a solitary $2 \times 2 \mathrm{~mm}$ sized painful swelling, brown-colored tumor arising from posterior wall of the right external ear canal that narrowed the external auditory canal with pus like discharge.
며, 후골부의 침습은 보이지 않았다. 약 한 달 후 펀치 생검을 시행한 부분이 궤양을 동반한 폴립 모양의 변화를 보여 연조 직 침범을 확인하기 위하여 자기공명영상촬영을 진행하였으 며 절제 생검술을 계획하였다. 만성 신부전 때문에 조영제를 사용하지 않고 촬영하였다. Fig. 2는 T1에서 저신호강도, T2 에서 고신호강도로 보이는 자기공명영상촬영 축영상 소견이 다. 입원하여 국소마취하 이개후방 접근법으로 우측 외이도 폴립에 대한 절제술을 진행하였다. 종양의 완전한 절제를 위 해서 이내절개술보다는 이개후방 접근법을 이용하여 시행하 였다. 수술 시 동결절편 검사에서는 절제연 양성소견을 보여, $2 \mathrm{~mm}$ 씩 확보하여 광범위 절제술을 시행하였고, 인공진피를 피부 결손 부위에 덮고, 수술을 종료하였다.

조직 검사 결과, 에크린 한선 낭종으로 확진되었다. Fig. 3 은 에크린 한선 낭종의 병리조직 소견이다. 낭성 공동이 진피 에 위치하고 있는 것이 보인다.

신체검사상 재발 병변이 보이지 않으며 상처가 잘 아물고 있는 상태임을 확인하였으며, 추후 6 개월마다 2년 동안 외래 추적 관찰을 할 예정이다.

\section{고 찰}

피부 부속기 신생물은 모낭선, 에크린 샘, 아포크린 샘 등의 정상 피부 부속물 중에 하나 혹은 하나 이상의 구조물이 형태
Fig. 2. A MRI axial view showing a mass (arrows) (A) T1-hyposignal, (B) T2-high signal intensity soft tissue. High signal in T2 shows signs of mastoiditis which is believed to have formed after time.

Fig. 3. Histopathology examination showed $(\times 200)(A)$, a cystic cavity located in dermis. The cystic wall present single layer of flattened epithelial cells can be seen, their flattended nuclei extending parallel to the cystic wall $(\times 400)(B)$.
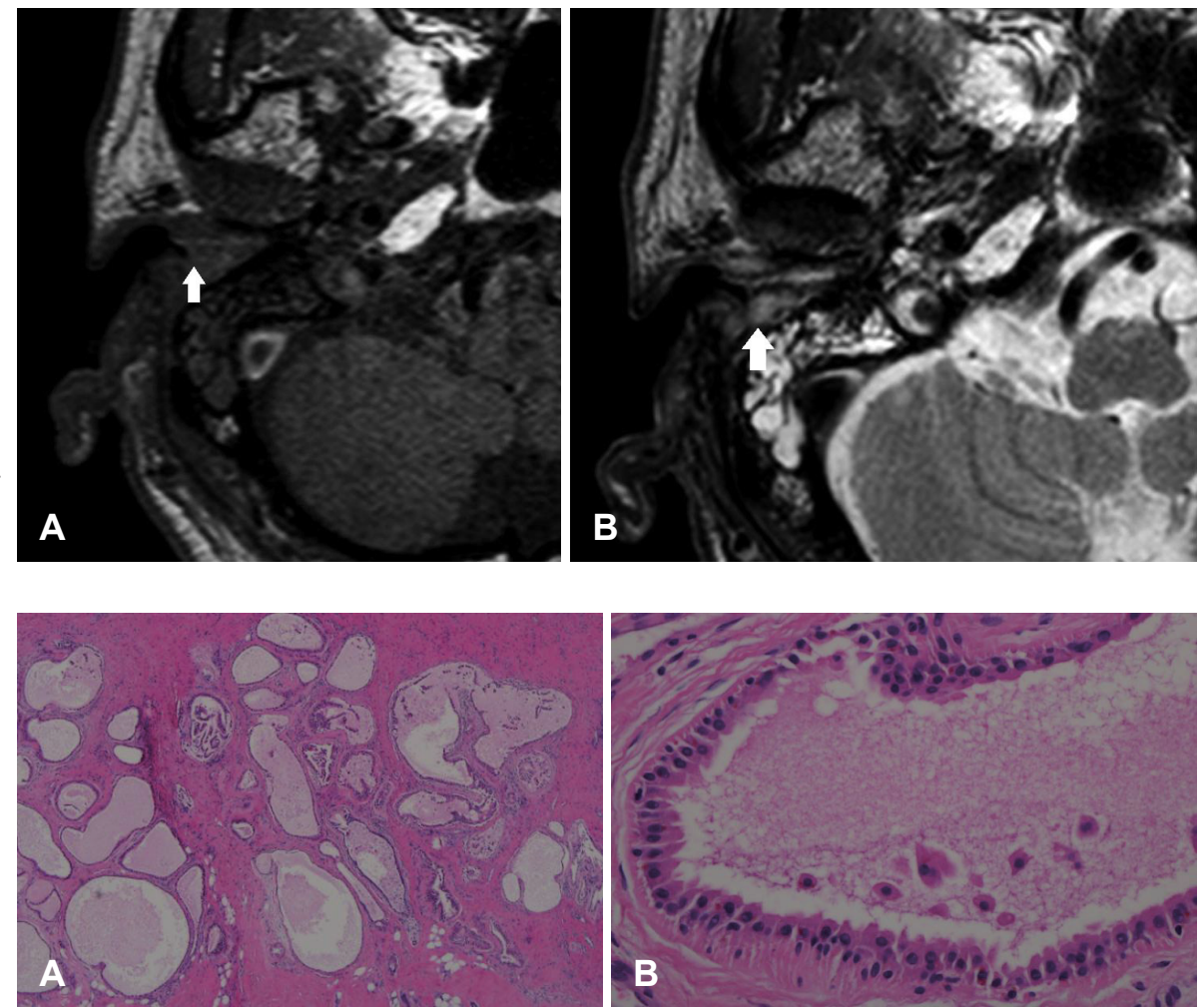
학적으로 변화한 것이다. ${ }^{1)}$ 조직학적으로 양성에서부터 악성 까지 다양한 스펙트럼을 보이는데 이에는 원주종, 한선종, 모 낭상피종, 모모세포종, 피지선종, 피지종, 피지악성 종양, 한선 종, 등이 알려져 있다. 대부분의 부속기 신생물은 양성이지만 불확실하게 절제된 경우 악성으로 변화할 가능성이 있다. ${ }^{1)}$ 특 히 비대칭적인 성장, 경계가 불확실한 경우, 배열이 일정치 않 은 경우, 비정상적인 핵, 유사분열의 활동 증가, 조직 괴사, 표 면적인 궤양 등이 있는 경우는 반드시 절제를 시행하여 재발 과 악성 변화를 방지해야 한다.

아포크린 한선 낭종는 양성 피부 부속 종양이고 보통 무증 상이지만, 전도성 청력장애나 이차적 외이도염을 일으킬 수 있기 때문에 넓은 주위 절제 및 외이도의 재건을 시행한다. 특히 완전히 절제하는 것이 재발을 방지하는 방법이다. 이미 보고된 4개의 증례에서는 모두 완전 절제 및 피부 결손 부위 를 후이개 피부 이식을 통해 재건하는 방법을 사용하였으며, 보고에 따라 16 개월에서 2 년까지 재발이 일어나지 않았다는 것을 보고하였다. ${ }^{1,3)}$ 단순 세침 천자, 절개 배농 등의 다른 치 료방법도 있지만 재발할 가능성이 높다. 아직까지 수술 후 악 성 변화를 한 경우는 보고된 바 없으나 모든 부속기관 종양은 불완전 절제 시 악성 변화의 가능성이 있다는 것을 염두에 두 어야 한다.

만약 조직 검사 결과 악성 종양으로 판명될 경우에는 높은 재발율 때문에 적극적인 치료가 권장되고 있으며, 기저세포 암종, 악성흑색종, 청색 모반, 땀관종 등은 한선 낭종과 반드 시 감별해야 한다. ${ }^{4}$ 시기에 따라 초기 종양은 외측 측두골 절
제술과 이하선 절제술 그리고 수술 이후 방사선 치료가 이용 되며, 진행한 악성 종양은 이보다 더 넓은 측두골 절제와 경 부 림프노드 절제술과 더불어 이하선 절제술과 방사선 치료 가 필요할 수 있다.

본 저자들은 외이도 후벽에 발생한 에크린 한 선낭종을 경 험하였으며, 국내에서 최초인 증례였다. 에크린 한선 낭종은 통증을 동반한 화농성 분비물이 특징적이다. 외이도에 발생 한 에포크린 땀샘낭종의 일차 치료는 국소적인 완전 절제 생 검이며 결손 부위는 후이개 피부나 인공 피부 이식을 통해 재 건한다. 또한, 정기적인 추적 관찰을 통하여 재발 혹은 감염 등의 합병증을 주의 깊게 관찰하여야 한다.

\section{Acknowledgments}

This research was supported by Basic Science research program through the national research foundation of Korea (NRF) funded by the Ministry of Education, Science and Technology (NRF-2015R1 C1A1A02036354).

\section{REFERENCES}

1) Ioannidis DG, Drivas EI, Papadakis CE, Feritsian A, Bizakis JG, Skoulakis CE. Hidrocystoma of the external auditory canal: a case report. Cases J 2009;2(1):79.

2) Anderson PJ. Apocrine hydrocysadenoma of the ear. Otolaryngol Head Neck Surg 2005;133(6):981-2.

3) Comacchio F, Pedruzzi B, Tava G, Alessandrini L, Marino F, Martini A. Eccrine hidrocystoma of external ear canal. Int Adv Otol 2012;8(2):333-8.

4) Shishegar M, Ashraf MJ, Azarpira N. Apocrine hidrocystoma in external auditory canal. Iran Red Crescent Med J 2007;9(1):42-4. 